\title{
Rooted in Christ, grounded in neighbourhoods - A theology of place
}

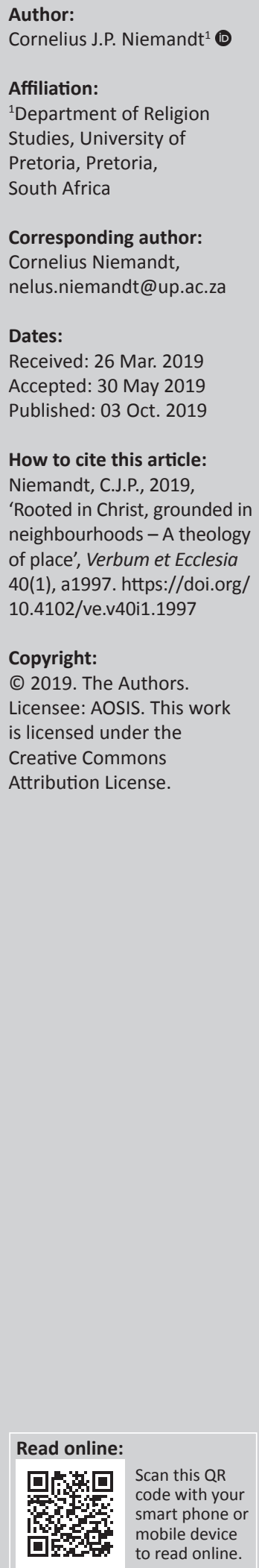

This research underscored the importance of developing a theology of place in the midst of a global sense of rootlessness, dislocation and displacement. This is significant because of the unfortunate lack of attention to theologies of place in Christian literature. It illustrated the possible rich contribution of mission theology to assist in developing a vision of place because of the emphasis on incarnation, contextualisation and inculturation in this theological discipline. This is enhanced by the important reflection on faithful presence and the restoration of the commons in missional ecclesiology. The research used literature study to develop the groundwork for a theology of place and to propose possible contours of a missiological engagement with a theology of place. This resulted in research that found that reality and contextuality demands a theology of place, which can be defined as an appreciation for the theological significance of specific geographic locations. The research developed the following contours of a theology of place, and introduced some ideas on each of these storied places, beautiful places, ugly places, holy and sacred places, places of exile and discomfort, places of healing and restoration, and quiet places. The research opened up a theological discourse on place and the implications of a theology of place for missional ecclesiology.

Intradisciplinary and/or interdisciplinary implications: This research challenges the relative lack of theological engagement with a theology of place and proposes an approach grounded in missional ecclesiology with its emphasis on incarnation to develop contours for a theology of place.

Keywords: beautiful places; commons; dislocation; faithful presence; holy places; incarnation; missional ecclesiology; places of exile; places of healing; places of reflection; theology of place; storied places; ugly places.

\section{Introduction}

The renewed attention to spirituality, and the emphasis on a missional spirituality that supports and nurtures missional life, can be summarised as an appreciation for a life rooted in Christ. This raises the question if missional spirituality is nothing more than a state of mind, an inner experience of faith.

The thesis of this research is that Christian theology, church praxis and especially a comprehensive missional approach to ecclesiology need to embrace place. Christian life and a healthy congregational culture must be grounded in the surrounding context - the neighbourhood. It acknowledges the re-emergence of place as a topic of concern in both sociological and theological work, and attempts to contribute towards the reflection on its implications for spirituality, congregations and mission. The aim of this contribution is to answer the research question: what are the contours of a missiological engagement with a theology of place? The scope of a research article limits this contribution to an introduction of the importance of the theme, establishing the importance of a theology of place and proposing the incarnation as an appropriate missiological point of departure to reflect on a theology of place.

The starting point is to acknowledge the imperative to communicate God to the context. Mission theology can help us to develop a vision of place because of the emphasis on incarnation, contextualisation and inculturation in this theological discipline. This provides a familiar conceptual framework for this particular focus in missional ecclesiology and spirituality. As much as the explosion in research in missional spirituality reminds us of the need of Christians to be rooted in Christ, Christians reflection and praxis must be grounded in neighbourhoods.

This research does not represent a fully fledged theology of place, but introductory remarks and a proposal of possible contours that might facilitate the development of a theology of place. 


\section{Grounded in neighbourhoods}

The gap in reflection on the relevance of place for theology is evident when one considers the approach that all previous models of contextualisation are inappropriate because of the change in contexts. A brief overview of some contextual realities reminds us of the importance of a faith rooted in Christ and grounded in context (see Niemandt 2017b:30-31). The South African landscape, and certainly much of the global landscape, is in the process of deep transformation because of a number of factors:

- The impact of globalisation and relentless migration, especially to urban areas. Some calls this the final great migration and predicts that mankind will be a wholly urban species (Saunders 2010:1). The Atlas of Global Christianity states the rate of urbanisation in Africa between 2000 and 2010 as 3.4\% per annum (Johnson \& Ross 2010:244).

- The continuation of vast disparities between the global north and the global south, as well as religious fundamentalism, witnesses to a context of deep inequality and growing social unrest.

- The focus on land issues in South African politics also reminds us that landscapes and spaces are all about land. Land is not only a political and economic issue, but also an emotional issue. For some, land tells a life story of sacrifice and hardship. For others, land symbolises suppression and emotions of deep loss and disenfranchisement. Land lies at the centre of many wars and conflicts. Places and land lie close to the heart.

The very texture of South African society is changing and not a single space is left untouched or unchanged. This reflects global realities and human mobility. All previous models or approaches to ministry and contextualisation of the Gospel are challenged by the 'new neighbourhood'. Not a single neighbourhood resembles the neighbourhoods of 25 years ago (see Niemandt 2017b:30-31). This results in a crisis of place in many societies - a sense of rootlessness, dislocation or displacement. There is a renewed urgency to reflect on a theology of place, and the relation between place, spirituality and missionality.

\section{The theological importance of place}

Place raises deep and probing questions because our relationship with land and place is complex. It is much more than mere ownership, for we do not have land, land has us. Place defines us - we are grounded beings. Place is central to geography and humanity (Inge 1999:43). Land shapes our identity and destiny. We all have a home, a place of origin, and we are in many ways similar to our places. We stay loyal to our identity and our places of the heart. Wepener (2018) argues that we are deeply entangled with land and that we always long for certain places. You can hear it in our songs and see it in our poems. This is why people may live in a different region, but still support the sports teams of generations ago. And this is why people remember stories of displacement and forced removal for generations. Land stands central in many emotional recollections of the past and feeds political unrest.

Land is indeed an important issue in terms of political ambition and feelings of well-being and content. Land and place are also important to faith. The entanglement of place and identity impacts faith. Faith is grounded and life plays in the many spaces we find ourselves in. The heartbeat of faith must be felt in concrete places of the heart (Niemandt 2018:11).

Places are important from a theological and spiritual perspective because it is part of our reality. Reality and contextuality demands a theology of place, which can be defined as an appreciation for the theological significance of specific geographic locations. It is rather unfortunate that theologies of place did not receive much attention in Christian literature. This may, in part, be because of a disenchanted view of the world of nature, separated from its Creator, under the influence of influence of the Enlightenment, as well as Reformed theology that divided the world of spirit and the world of matter. Granberg-Michaelson (2017:68) explains that secularism constructed a view of nature and the material world that segregated it from God. Reformed theology created a perfect storm by protecting the life of the Spirit from material contamination, and Enlightenment constructed a worldview that pushed God to the margins, '... acting like a whirlwind', says Granberg-Michaelson (2017:68), 'to empty the created world of any sacred significance'. But, admits Perriam (2014:23), even geography neglected religion as an axis of geographical enquiry.

We enact faith in the reality of this world and the places we find ourselves in. Life originated from the earth, and we cannot but live a grounded life and faith. Land, place and faith go together. We need a theology of place or geography. Conradie (2009:3) says that a theology of place has deep roots in the Jewish-Christian tradition. The core themes of the Christian faith are closely tied up with a theology of place. Conradie (2009:4) mentions creation, continuing creation and history, human culture and sin, God's providence, redemption in history, church and mission, and eschatological fulfilment. It is also important to note that a theology of place is not the same as a theology of space (Conradie 2009:8).

God is present in creation. 'The deepest intuition of a theology of place has to do with this core Christian insight,' says Conradie (2009:4), 'that the triune God is not a distant sky divinity or a deist clockmaker who observes things from above but does not interfere with what is happening on earth'.

God is the Creator of all places. One can interpret the two creation stories in Genesis 1 and 2 as follows: God created the rhythm of time and the course of life (Gn 1). Everything was created in 7 days and this allows for an overarching rhythm and flow in life. Genesis 2 alludes to the fact that God created a specific place as part of creation. The description of the 
Garden of Eden anchors the following narratives in specific places. Everything started somewhere in a specific place - a place with clear borders, space and content - a geographical reality. This place is described as a garden. A grounded place. It is bordered by rivers, but also has a destiny. The Garden of Eden is not an unlimited everywhere, but a defined place (Niemandt 2018:13; Peterson 2005:65-75):

Now the LORD God had planted a garden in the east, in Eden; and there he put the man he had formed. (Gn 2:8 New International Version [NIV])

Peterson (2005:72) argues 'All living is local ...'.

God is present in all places. The world is sacred. The moment our lives become aware of God's involvement in all places, we discover God's presence. One only needs to reflect on the rich implications of Acts 17:

... he marked out their appointed times in history and the boundaries of their lands. God did this so that they would seek him and perhaps reach out for him and find him, though he is not far from any one of us. For in him we live and move and have our being ... (vv. 27-28)

Peterson (2005) addresses this issue in Christ plays in ten thousand places. The poem 'As kingfishers catch fire' by Gerard Manley Hopkins says much:

I say more: the just man justices;

Keeps grace: that keeps all his goings graces;

Acts in God's eye what in God's eye he is -

Christ. For Christ plays in ten thousand places,

Lovely in limbs, and lovely in eyes not his

To the Father through the features of men's faces

We need places to be fully human. If we want to accomplish God's mission, to the glory of God, we cannot settle for an abstract life in general. We live and flourish in particular conditions - the same where God works, namely time and place. We are not disembodied angels. We have a street address where God can find us (Peterson 2005:84).

God created all places, is present in all places and everything belongs to God. Granberg-Michaelson (2017:83) calls the restoration of the relationship between the active presence of God in the world one of the most important challenges that can reshape Christianity - 'Christianity must once again learn to perceive a sacred world' (GranbergMichaelson 2017:83). We are stewards and guests. The real owner of all land is the Creator of all places. Wepener (2018) explains:

All inhabitants of the earth and tillers of the land are guests, guests of the Host who are the actual owner of the land. Those who inhabit and cultivate the land are strangers and temporary visitors. (n.p.)

\section{Incarnation and place}

The concept of incarnation is especially helpful in the reflection on a theology of place. The incarnation is a key paradigm in theology, especially in mission studies and the process of contextualising and inculturation. Bass (2015:20) explains: 'The language of divine nearness is the very heart of vibrant faith'. Fitch (2016:loc. 401) also argues that the great commission is fulfilled when missio Dei and incarnation come together in one concrete place. Inge (1999:46) explains that places are the seat of relations or the place of meeting and activity in the interaction between God and the world. The doctrine of the incarnation provides a very strong argument to illustrate the integral unity between the material and spiritual dimensions of creation (Granberg-Michaelson 2017:82). The incarnation of God helps us to understand that God presupposes the nature of all the living (Moltmann 2015:128). Gregersen (2015:7) explains that God became a human, social, living and material being.

This also impacts ecclesiology. The life of the church as life in the Trinity, and the fundamental importance of the incarnation as a movement towards where people are (place), forms the basis of a missional ecclesiology. Hirsch (2006:132) explains the importance of a missional-incarnational impulse and refers to the importance of presence and proximity from and incarnational perspective. Because God became fully present to us in Jesus Christ, and because God approached us in Christ in ways we can understand and access, an incarnational lifestyle also entails presence and proximity. The church must be present inasmuch as God became present in Christ: 'Jesus actually likes to hang out with the people we hang out with' (Hirsch 2006:134). Proximity implies genuine availability, '... as well as regularity in the friendships and communities we inhabit' (Hirsch 2006:134).

An important step in the establishment of the theological importance of place is a rediscovery of the 'commons'. Brewin (2012:loc. 1264) uses this idea to describe the interests of the community, and the use of resources for the sake of the common good. When we use what we own, the idea of the commons demand that we are obliged to think about our neighbours because we share life with these others. Brewin (2012) applies this idea to a very novel social constructionist interpretation of piracy:

To put it another way, wherever we see piracy we are looking at a system in trouble, a trading structure that is unjust, perhaps because it has taken something that should be the 'common property' of all people and locked it behind a pay-wall, perhaps because it refuses to share the spoils of wealth with those who have laboured so hard to create it. (loc. 143)

We live in a privatised culture where people privatise everything for private use. Jethani (2009:142) warns that the suburb is the last word in privatisation, perhaps even its lethal consummation, and it spells the end of authentic civic life. Niemandt (2015:342) applies the focus on the commons to research in missional ecclesiology and states that pirates can be understood in terms of a critique of individualism. Pirates break the chains of privatisation, in an effort to restore the commons. The commons is the space where life is shared with the lives of others - 'the theatre in which the life of the community was played out' (Brewin 2012:loc. 715). Sparks, Soerens and Friesen (2014:loc. 208) talk about the new 
commons as all dimensions of life for which everyone in a neighbourhood shares a common concern. It is an issue of radical sharing, and of using the free flow of information and goods for the common good. This idea of the 'commons' provides fresh insights in a new approach to neighbourhoods and thus a theology of place.

\section{Faithful presence}

The church needs to establish a faithful presence in the commons. Faithful presence means, according to Sparks et al. (2014:48), taking your bodies, your location and your community very seriously, as seriously as God in Christ took them: 'Faithful presence invites you to act on the belief that God is giving you what you need to be formed as disciples within your location'. Faithful presence is an integral concept in a theology of place. Fitch (2016) argues that faithful presence names the reality that God is present in the world and that God uses people faithful to his presence to make himself concrete and real in the world. Fitsch re-interprets the incarnation and relates it to the missio Dei, and says when the church is faithfully present, God's kingdom becomes visible: 'it's how God has chosen to change the world' (Fitch 2016:loc. 55). Faithful presence is at the heart of what it means to be the people of God (Fitch 2016:loc. 87).

This is similar to the approach of Bass, when she refers to the term 'grounded'. She argues that ' $t$ this world, not heaven, is the sacred stage of our times' (Bass 2015:26). God is a 'grounded God' because God is a God in relationship with space and time as the love that connects and creates all things, known in and with the world. It is a new awareness of the earth and the presence of God in neighbourhoods. Home and place is of the utmost importance because home is the geography of our souls (Bass 2015:166). Bass (2015) describes this as a radical change in the way many people understand God and how they practise faith:

God is in the ground, the grounding that which grounds us. We experience this when we understand that soil is holy, water gives life, the sky opens the imagination, our roots matter, home is a divine place, and our lives are linked with our neighbours' and with those around the globe. (p. 26)

Faithful presence implies a specific kind of presence in all the places that Christians find themselves - and in such a way that it affirms the integrity of Christian faith. The church is a hermeneutic of the gospel - it brings the gospel story but is also, in its life and witness, the gospel (Newbigin 1989:222-233). The church is the gospel and restores life in each and every place God's people find themselves. It is a question of trust - to be able to trust God's people and to entrust the place where they live, work and play. Sweet (2009:163) argues that the incarnation story is a story one can trust because it tells the unvarnished truth about life. Faithful presence has a double ring: it is the kind of presence that establishes the good faith of people of faith. It is a presence that serves places, people and looks after the interests of the others (Phlp 2:4). It is also the kind of presence that shows Christian faith can be trusted and valued. It is a life true to Jesus Christ, the head of the church - a living and trustworthy witness that will facilitate faith because Christians are faithfully present.

The concept of faithful presence raises important questions in ecclesiological praxis. This means congregational leaders and custodians of church vision will need to ask at least some of the following questions:

- To whom are we sent?

- Where are we to be faithfully present? Locality demands rather clear borders.

- How can we define the place we want to be faithfully present?

- What is our civic ecosystem?

\section{Milestones in the development of a theology of place}

The development of a theology of place, the restoration of the commons and attention to the implications of being faithfully present suggest attention to various aspects of place - to the contours of a missiological engagement with a theology of place. The following contours might provide fertile ground to nurture a theology of place: storied places; holy places, places of exile and displacement; places of quiet reflection; places where beauty and life flourish; ugly places; and places of healing and restoration.

\section{Storied places}

One of the first aspects that needs attention is the many stories in the Bible where place plays an important role - the prevalence of storied places in the Old and New Testament. Brueggemann coined the concept of storied places, stating that there is no timeless space and no spaceless time. Places have meaning because of the history lodged in those spaces. Stories have authority because they are located in a place. Neither Old nor New Testament escapes this 'rootage' (Brueggemann 1978:187). The power of narrative also explains the difference between space and place. Place is a space filled with meaning because of the narrative(s) connected to the particular space. These narratives provide continuity and identity across generations: 'Places are storied spaces' (Lane 1988:11). Place has theological significance because of the narratives connected to and the stories told by the place. In a certain sense, stories transform empty space into a vibrant place. In terms of the relationship between place and the experience of the transcendent, Inge (1999:47) explains that sacred places will be those that have been associated with sacred stories - places linked with divine disclosure. Conradie (2009:3) says that one can summarise the gist of biblical narratives with a symbolic list of 12 geographic locations: Eden, Ararat, Ur of the Chaldeans, house of slavery in Egypt, Canaan, Jerusalem, Babylon, Bethlehem, Nazareth, Golgotha, Antioch and Rome.

A theology of place needs to take cognisance of and appreciate the importance of narrative in forming the identity of place. The abundance of stories centred on place in Old and 
New Testament narratives provides a rich source of research, and reading these stories with a missional hermeneutic (see Goheen 2016:15) might contribute to the development of a theology of place. Such a hermeneutical approach attends to mission as central to the biblical story, the conviction that mission is the dominant motif and framing metanarrative in the biblical story, and reading Scripture with the conviction that it equips the church for missional praxis (see e.g. Gorman 2018).

\section{Holy and sacred places}

Another contour of a missiological engagement with a theology of place that flows from the attention to storied places in the biblical narratives is to attend to holy and sacred places. Places linked to a special perception or experience of God's presence are well known. Theologically speaking, God is omnipresent. God is even present where we least expect to find God. But God is also a mystery and hidden. Inge (1999:47) argues for a balanced approach between God being in holy places and God being everywhere, understanding that we encounter God in some places in order that we might find God everywhere. We need to appreciate the importance of perceiving the world as a sacred place, and holy places remind us of the integral unity between the material and spiritual dimensions of creation. Moses had to learn that you cannot always look God in the eye and stay alive. But people are always trying to find God in holy places - a quest that seems to be unquenchable, even in modern times. People will dedicate much time and sacrifice to embark on difficult pilgrimages to experience the 'different presence' of God in holy places.

Thiessen and McAlpine (2013:136) refer to people saying that they connect to a higher power in a sacred space - people have 'a basic human need to want to believe in something bigger and higher than yourself'. Their research found that for some people sacred space is a catalyst to connect with themselves and God; important connections because they help to centre individuals' lives with meaning and direction in life. This function of holy places is fulfilled when people think about sacred space 'as (a) a meeting place between Heaven and Earth, God and humanity, and (b) an earthly representation of beauty' (Thiessen \& McAlpine 2013:136). There is a geography of holy places because holiness becomes incorporated into an understanding of a place (Inge 1999:46).

Foucault spoke about heterotopia [hétérotopie] - a place people long for but can never control. This place represents more than meets the eye and has multiple layers of meaning. I find Wikipedia's (2019) description quite satisfying:

Heterotopia is a concept ... to describe certain cultural, institutional and discursive spaces that are somehow 'other': disturbing, intense, incompatible, contradictory or transforming. Heterotopias are worlds within worlds, mirroring and yet upsetting what is outside.

People long for these 'other' places, especially because we experience 'a crisis of place in Western societies - a sense of rootlessness, dislocation or displacement' (Thiessen \& McAlpine 2013:136). Granberg-Michaelson (2017) describes this as a perfect storm that endangers human life and life as we know it:

Emptying creation from its intrinsic, sacred value, derived from the life of the Creator, now threatens the actual sustainability of the planet's life-supporting systems. Climate change is the most telling sign of this threat ... (p. 70)

Sacred places help people to re-establish roots, to become located and 'grounded' in the world. Some places acquire, through time and frequent visits, or compelling narratives, a history of 'being different'. Churches become sacred places. Places with rich histories of healing become places of pilgrimage. Thiessen and McAlpine (2013) explain:

One of the reasons that sacred space helps to ground people is because it is believed to be a meeting point between Heaven and Earth, a dedicated space for communication between God and humanity. (p. 137)

People visit these places with the expectation that they might connect with God. Heterotopia explains that there is indeed more than meets the eye. The expectation gives birth to an experience. Thiessen and McAlpine (2013:137) say that when people walk through doorways into sacred spaces, they are mindful of both the transition from the profane into the sacred and, perhaps more importantly, the transition taking place in their lives.

Although the veil between the holiest of holies and the rest of the temple was torn apart when Jesus Christ died on Golgotha, and forever changed the experience and perception of the presence and accessibility of the Holy One, I am convinced that sacred and holy places are a gift from the Holy Spirit. Following Inge (1999:47), one can argue that these places are consecrated and holy, not instead of the whole, but on behalf of the whole. As much as God revealed Godself to Abraham in the burning bush, and as much as the Bible relates many stories of sacred places, sacred places remind us that the membrane between our reality and a deeper reality is quite thin (Niemandt 2018:48). 'Sacred spaces embrace those present', say Thiessen and McAlpine (2013:139), 'while at the same time, like a word or a symbol, they denote something beyond both the participant and the context'.

A theology of place acknowledges the importance of holy places, and mission studies need to reflect on the missional impact and importance of these places. We need holy places to stem the eclipse of the sacred and the emptying of creation of its sacred value. Wright (2010:1oc. 2389) argues that holiness reflects God's own holiness and that it is thoroughly practical, social and very down-to-earth. It ought to be as down-to-earth as to be able to reflect on holy places in the grounded reality of everyday lives.

\section{Places of exile and displacement}

Although the biblical narratives are conducive to attend to the particularity of specific places, the theme of exile and the 
discomfort of displacement necessitate a theology of place that attends to the loss of place as well.

Many of the biblical narratives introduce the reader to strange and unfamiliar places. God's people regularly ended up in places of exile and discomfort. Even though particular places play a big role, it is equally true that people easily cross borders and explore new places, or that people are forcefully relocated or displaced. Many of the stories in the Bible have everything to do with people leaving familiar places and crossing borders. The ultimate role model might be Abraham, who is called to trust in God alone and embark on a lifechanging journey to a foreign land. His agenda comprises visits to many strange places:

The Lord had said to Abram, 'Go from your country, your people and your father's household to the land I will show you'. (Gn 12:1 NIV)

A major section of Israel's history relates narratives of unfamiliar or strange places. These stories narrate experiences of desolation, uncertainty and irrelevance. This is the life of exiles. One has to cross borders and cope with uncertainty. You become an exile - someone looking for God, and life, in a strange and unfamiliar place.

Frost (2006:8) stated that the contemporary Christians' experience is one of dislocation, uncertainty and irrelevance, and that Christians might find many parallels between their life and the Old Testament Jewish exiles in Babylon: 'The biblical metaphor that best suits our current times and faith situation is that of exile' (Frost 2006:9). Although many biblical narratives relate to political undercurrents and exile, there may also be other reasons for exile. Some people are in economic exile and must find economic refuge in a foreign place. Some people are in exile because of the collapse of family life (perhaps a divorce) and this results in finding new hope and life in an unfamiliar place.

Participating in God's mission, more often than not, also leads to places of exile and discomfort. Niemandt (2017a:2) says, '[Missionaries] are the agents who, in one way or another, facilitate movement, trade, flow and life in the midst of the shadows of walls'. When Jesus sends out 72 disciples to gather the harvest ( $L k 10$ ), he sends them to strange and unfamiliar towns and places. They become dependent on the hospitality of those they are sent to. They reside among strangers and bring peace in unfamiliar surroundings. Paul can certainly be described as one of the most influential missionaries of all time. Bosch (1991:130) describes Paul's mission as the combination of wandering preachers and diaspora Greek-speaking Christian Jews. Paul was engaged in Zentrumsmission - mission in certain strategic centres.

Embracing exile and strange places entails risk. It is a question of shifting boundaries and a willingness to venture into foreign environments and to be present in strange places. Frost and Hirsch (2011) remind us:
The church should be one of the most adventurous places on earth - the locus of all quest, the highly adaptive Jesus community at the very forefront of what God is doing in the world. (loc. 286)

A theology of place recognises the importance of travel. As much as place defines a person's identity and formed worldview, travel can liberate a person and deepen faith. It liberates a person from the claustrophobic effects of a limited place and limited ways of expressing faith. When we travel, take risks and explore strange places, we move into liminality, and might discover that God can surprise us. Travel narratives are narratives of hope and new life. They are testimonies of God's presence and grace in strange places of exile; testimonies of his providence and closeness.

\section{Places of quiet reflection}

Although places of quiet reflection are not necessarily obvious in many of the biblical stories that play out in place, this aspect has developed into a major issue in many Christian traditions, in Christian spirituality and in ecclesiological praxis. The reflection on contours of a theology of place cannot ignore reflection on quiet places.

Spirituality must embody the gospel. Although the focus of embodiment may be the human body, it also relates to place. When Guder (2005:22) argues 'The centrality of the community to the gospel means that the message is never disembodied. The word must always become flesh, embodied in the life of the called community ...', the embodying of the gospel certainly happens in a real place. Granberg-Michaelson (2017:76) recognises the importance of contemplative voices in the reconnection between material and spiritual reality, and the appreciation of the sacredness of all life. He observes how intense interior journeys 'end up discovering God's presence permeating all things in a sacred canopy of infused love' (Granberg-Michaelson 2017:76).

Attention to Christian spirituality recognises the importance of places of quiet reflection and retreats. Quiet places are places where time and space merge and places that facilitate another reality or consciousness. It helps a person to be simply present differently. To be aware of the graceful presence of the Triune God. The inward journey sanctifies the material world, and requires quiet places.

A Christian spirituality needs a place of quiet reflection. There is a general consensus stretching over centuries of Christian tradition and practice, and supported by all denominational and theological camps - Christian growth needs silence and the fertile earth of quiet places (Jethani 2009:33).

Jethani (2009) reminds us: 'Silence is a rare commodity in our world':

But humble silence offers us liberation from our digital cocoons to experience wonder once again. Silence allows us the space to contemplate the vastness of the heavens and the God beyond 
them. Silence can shatter the trivialized deity that has occupied our imaginations and provide God the canvas to begin a new work in our souls. (pp 33,46)

Perriam (2014) observes, from the perspective of medical science, that spiritually significant experiences can occur in a number of ways, and in many different forms and settings, and in particular places:

Common threads among spiritual experiences are the recognition of some greater meaning or dimension to life, emotional engagement at some deeper level, even if momentary, a sense of purpose and the connection of all of these elements with well-being, whether physical, emotional or both. That such experiences are often connected to place and indeed, particular places, are of interest to a spatially sensitive medical humanities. (p. 22)

An authentic Christian spirituality is embodied and grounded in place. Christians need places of reflection to stay rooted in Christ and to appreciate the connectedness between the material and spiritual word, even to be able to participate in God's transformation of his creation.

\section{Places of beauty and flourishing life}

Volf emphasises the importance of flourishing life, especially for the theology. He argues that the 'flourishing of human beings and all God's creatures in the presence of God is God's foremost concern for creation and should therefore be the central purpose of theology' (Volf 2019:11). This certainly includes reflection on places where life flourishes, or places of beauty and flourishing life.

In terms of a theology of place, it has already been stated that the point of departure is the conviction that God is present in all of creation. Christianity must perceive a sacred world. The Westminster Directory of Public Worship states in an appendix about the days and places of worship: 'As no place is capable of any holiness' because the Reformation rejected those things 'discovered to be vain, erroneous, superstitious, and idolatrous' (Granberg-Michaelson 2017:66). This illustrates how the Reformed legacy emptied creation of its intrinsic, sacred value and beauty, and appreciation for flourishing life, laying the groundwork for a utilitarian and exploitative approach to nature itself. Add to this the potent impact of modernism, where we have come to live 'disembedded' lives (Volf 2019:20). Unfortunately, the issue of true, good or flourishing life, and the truth and beauty of human existence, is neglected today but more urgent than ever (Volf 2019:2, 8).

The concept of flourishing life, and the truth and beauty of life, restores a focus on beautiful and flourishing places. We need to recapture the ancient theological approach to understand redemption as the redemption of the whole creation, and the intrinsic connection of humanity with creation. This includes 'perceiving the world as God's cathedral', a journey, says Granberg-Michaelson (2017:84), which 'is indispensable for our future'. Places of beauty can act as natural cathedrals that facilitate reflection on creation and the Creator. It creates space and places to be aware of God's goodness, creativity and care. A theology of flourishing places is an important part of theological reflection. Flourishing, beautiful places serve as reminders of the presence and activity of God, and our longing to participate in God's creative acts of beauty and sensemaking. Places of beauty remind us what flourishing life can look like.

The creation narratives in Genesis remind us that God created everything - '... and God saw that it was good' (Gn 1:9-24). There was an inherent beauty in the flourishing creation that pleased God, and God is still busy restoring and renewing creation to new and pleasing glory.

Participating in God's mission most certainly implies participating in God's work to restore beauty and joy to all of creation, and to enjoy and care for beautiful places. If not, the disconnection between God and creation will continue, and more and more people will imagine a God that does not desire to save the world. The appreciation of places of beauty, and the reconnection between faith, beauty and place, is of vital and life-giving importance. In terms of the missiological approach to this research, one can argue that mission studies are to re-interpret the missio Dei in terms of flourishing life in the light of God's self-revelation in the incarnate Christ.

The importance of theological reflection on places of beauty is evident when one considers the worldwide billion-rand tourism industry. The industry not only sells experiences associated with the natural beauty of many places, but also impacts the sustainability of the very product it sells. This raises many ethical and theological questions.

Places of beauty also raise questions regarding beauty itself, and the relationship between beauty and theology. Marais (2019:7) summarises the gift of beauty by referring to Dostoevsky's famous statement: 'The world will be saved by beauty'. She argues that the church must be able to look deeper and discern better, to be able to observe beauty. To observe beauty is simultaneously an acknowledgement of our deepest longing and an expression of faith. Beauty is an expression of flourishing life. We long to find beauty, but paradoxically also destroy beauty. Grace is the ultimate gift of beauty. It redeems us from sin, but also recalibrates our lives and sense to be able to observe and enjoy beauty. Grace helps us to appreciate flourishing life as the Creator intended it.

A theology of place attending to beautiful, flourishing places might be guided by Volf's (2019:16) tripartite structure of attending to life going well, life led well and life feeling as it should. Life going well refers to the 'circumstantial' dimension of the flourishing life, including natural circumstances and our deep relationship to place and land. Life led well refers to the 'agential' dimension of the flourishing life, to the way humans conduct themselves in relation to the places they inhabit and how they take care 
of creation. Life feeling as it should is about the 'affective' dimension of the flourishing life, about enjoying beauty, contentment, joy and empathy.

\section{If life does not flourish - Ugly places}

Beauty is in the eye of the beholder - ugliness as well. People have diverging views on beautiful and ugly places and display remarkable diversity. Perhaps this explains why some people enjoy desert landscapes and others flock to golden beaches or lush forests. A theology that addresses ugly places refers to places that are destroyed or damaged by mankind, places where life is diminishing and not flourishing any more. Marais (2019:7) reminds us that beauty can be used and manipulated to serve evil, and that the very mankind who longs for beauty also destroys beauty. We find many ugly places scarred by mankind: nature destroyed by mining activities; places that recall the worst in human history; places where the very name conjures up images of hate, pain and loss: Majuba, Robben Island, Slagtersnek, Sharpeville, Marikana. Judge Albie Sachs (2015) talks about 'Sites of memory, sites of conscience', referring to places such as the Apartheid Museum, Liliesleaf, District Six Museum and Robben Island.

Some places gain political and symbolical significance. Afrikaans artist Laurika Rauch captured some of this in her moving rendition of 'Hot Gates' when she sings about:

Balaklava, Austerlitz, Belsen, Buchenwald, Auschwitz, Nagasaki, O Versailles, Armageddon, Thermopylae ...

Place and land are never neutral. The soil is the first victim of human evil; as a result of Adam and Eve's disobedience and Abel's murder, the land is wounded, crying and bloodied (Bass 2015:57). And yet, God is also present in ugly places. Christ's love does not recoil from our misery. God does not turn his back on those places we associate with the worst in mankind. God hears the cries rising from creation and mankind and turns towards ugly places to restore beauty and breathe new life into those places so that life can flourish again. God is present where we least expect God, and more so where the least and marginalised cry out for help and comfort. 'God deals with us', explains Peterson (2005:75), 'where we are and not where we would like to be'. This might help people who perceive the places where they find themselves to be places that must be abandoned at all cost. It might be the very place where the restorative presence of the Spirit might be most evident. Marais (2019:7) comforts us: 'Our tragedies, pain, our terrible circumstances - everything that we are never ever able to associate with beauty - comes to rest in God's restorative beauty'.

Perhaps Afrikaans novelist Krog (cited in Van Schalkwyk 2006) says is best in Country of my skull:

Because of you, this land no longer lies between us but within. It breathes becalmed, after being wounded in its wondrous throat. In the cradle of my skull it sings, it ignites my tongue, my inner ear, the cavity of heart, shudders toward the outline new in soft intimate clicks and gutturals ... because by a thousand stories I was scorched a new skin. I am changed forever. I want to say: Forgive me. Forgive me. Forgive me ... (p. 116)

A theology of place acknowledges that ugly places where life ceased to flourish can be restored by the Spirit and can be made a place 'in which God's presence can be concretely experienced' (Volf 2019:69).

\section{Places of healing and restoration}

The transformation of ugly places and the restoration of flourishing life remind one of the importance of places of healing and restoration. There are wonderful narratives in the Bible about healing and recovery. The bath at Bethesda and the miracle Jesus performed there (Jn 5: 1-17) comes to mind. Another example is Elijah and his time of restoration in the desert (1 Ki 19:3-18).

The burgeoning health industry reminds us that the world is desperately looking for healing and restoration. Health spas are extremely popular and represent one of the fastest growing industries worldwide - perhaps because people need places of recovery and healing. 'Throughout the ages mankind has sought healing for injuries, acute illness, and chronic disease', says Talbot (2002:153), 'whether from academically trained physicians, from shamans, or at miraculous shrines'. We are familiar with health spas, especially associated with hot spring water, which have been known for their healing powers for as long as people can remember. It started as an important vacation industry with people visiting these places for healing and physical restoration.

The restoration of flourishing life has as much to do with living waters flowing as with the presence of the living God. When visitors open themselves up to God and perceive God's presence, the place becomes a place of restoration and healing. It restores life and direction in life. It is a kind of restoration that allows life to flourish anew.

In certain cases these places of healing and restoration develop into sacred places of pilgrimage. The very fact that some of these places became well known because of stories of miracles and supernatural healing leads to a combination of sacred presence and healing in one place. These healing shrines are well known: Lourdes, Fátima, Virgin of Guadalupe and Sainte-Anne-de-Beaupre, to name but a few. These places illustrate that the relationship between place, spirituality and healing continues today as people still seek healing of body, mind and spirit in similar sites. The term 'therapeutic landscapes' has been used, especially in medical literature, to describe physical locations considered to be beneficial to healing and well-being in health settings (Perriam 2014:22). Therapeutic landscapes include mainstream health settings such as hospitals, places where 'alternative forms' of healing are practised, places associated with healing and sainthood, and places that offer respite and retreat into stillness. These are places where 'hope flourishes 
over time' (Perriam 2014:23), and where life is restored and begins to flourish again.

A missional church attends to and is involved in the healing of people. Healing refers to 'wholeness', 'welfare' and 'flourishing'. Mission serves and participates in God's lifegiving mission. The Old Testament concept of shalom which refers to physical health, peace of mind, healthy human relations, social justice and peace with God - expresses this wholeness aptly. A theology of place engages in the reflection on therapeutic landscapes, places of restoration and healing, and the theological issues regarding health and the location of healing.

\section{Conclusion}

This research underscored the importance of developing a theology of place in the midst of a global sense of rootlessness, dislocation and displacement.

It illustrated the possible rich contribution of mission theology to assist in developing a vision of place because of the emphasis on incarnation, contextualisation and inculturation in this theological discipline. This is enhanced by the important reflection on faithful presence and the restoration of the commons in missional ecclesiology.

From this the research proposed possible contours of a missiological engagement with a theology of place, attending to storied places, beautiful places, ugly places, holy and sacred places, places of exile and discomfort, places of healing and restoration, and quiet places.

\section{Acknowledgements Competing interests}

The author declares that he has no financial or personal relationships that may have inappropriately influenced him in writing this article.

\section{Authors' contributions}

C.J.P.N. developed the conceptual work, did all the research and compiled the research article.

\section{Ethical considerations}

Ethical approval for the study was obtained from the Ethical Committee: Faculty of Theology and Religion, University of Pretoria. Ethical clearance certificate: In process.

\section{Funding information}

This research was supported by the National Research Foundation (IFR160225159142).

\section{Data availability statement}

Data sharing is not applicable to this article as no new data were created or analysed in this study.

\section{Disclaimer}

The views expressed in this article represents the views of the author and does not represent the official position of the University of Pretoria.

\section{References}

Bass, D.B., 2015, Grounded: Finding God in the world - A spiritual revolution, Kindle edn., HarperCollins, New York, NY.

Bosch, D.J., 1991, Transforming mission: Paradigm shifts in theology of mission, Orbis, Maryknoll, NY.

Brueggemann, W., 1978, The land: Place as gift, promise and challenge in biblical faith, SPCK, London.

Brewin, K., 2012, Mutiny! Why we love pirates, and how they can save us, Kindle edn, Vaux, London.

Conradie, E.M., 2009, 'Towards a theology of place in the South African context: Some reflections from the perspective of Ecotheology', Religion and Theology 16, 3-18. https://doi.org/10.1163/156973109X449967

Fitch, D.E., 2016, Faithful presence: Seven disciplines that shape the church for mission, Kindle edn., InterVarsity Press, Downers Grove, IL.

Frost, M., 2006, Exiles: Living missionally in a post-Christian culture, Hendrickson, Peabody, MA.

Frost, M. \& Hirsch, A., 2011, The faith of leap: Embracing a theology of risk, adventure \& courage, Kindle edn., Baker, Grand Rapids, MI.

Goheen, M.W., 2016, 'A history and introduction to a missional reading of the Bible', in M.W. Goheen (ed.), Reading the Bible missionally, pp. 3-27, Orbis, Maryknoll, NY.

Gorman, M.J., 2018, Abide and go: Missional theosis in the Gospel of John (The Didsbury Lecture Series Book), Cascade Books, Eugene, OR.

Granberg-Michaelson, W., 2017, Future faith: Ten challenges reshaping Christianity in the 21st century, Fortress Press, Minneapolis, MN.

Gregersen, N.H., 2015, 'Introduction', in N.H. Gregersen (ed.), Incarnation: On the scope and depth of Christology, pp. 1-21, Fortress Press, Minneapolis, MN.

Guder, D.L., 2005, The incarnation and the church's witness, Wipf \& Stock, Eugene, OR.

Hirsch, A., 2006, The forgotten ways: Reactivating the missional church, Brazos, Grand Rapids, MI.

Inge, J., 1999, 'Towards a theology of place', Modern Believing 40(1), 42-50. https:// doi.org/10.3828/MB.40.1.42

Jethani, S., 2009, The divine commodity: Discovering a faith beyond consumer Christianity, Kindle edn., Zondervan, Grand Rapids, MI.

Johnson, T.M. \& Ross, K.R. (eds.), 2010, Atlas of global Christianity 1910-2010, Edinburgh University Press, Edinburg.

Krog, A., 2009, Country of my skull, Random House Struik, Cape Town.

Lane, B., 1988, Landscapes of the sacred: Geography and narrative in American spirituality, Paulist Press, Mahwah, NJ.

Marais, N., 2019, 'Die geskenk van skoonheid', Kerkbode, 15 February.

Moltmann, J., 2015, 'Is God incarnate in all that is?', in N.H. Gregersen (ed.), Incarnation: On the scope and depth of Christology, pp. 119-131, Fortress Press, Minneapolis, MN.

Newbigin, L., 1989, The Gospel in a pluralist society, Eerdmans, Grand Rapids, MI.

Niemandt, C.J.P., 2017a, 'Mission as breaking down walls, opening gates and empowering traders: From contextualisation to deep contextualisation', HTS Teologiese Studies/Theological Studies 73(3), 4621. https://doi.org/10.4102/hts. v73i3.4621

Niemandt, C.J.P., 2017b, 'Towards a Missiological vision of place', in P. Aurel \& D. Buda (eds.), Making mission from the Model of Christ Parish and Monastery today: Challenges and spiritual and communitarian implications, pp. 30-47, Astra, Sibiu.

Niemandt, N., 2015, 'Together towards life: Sailing with pirates', Missionalia 43(3), 336-348. https://doi.org/10.7832/43-3-88342

Niemandt, N., 2018, Hartsplek: Egte lewe waar jy is, Bybelmedia, Wellington.

Perriam, G., 2014, 'Sacred spaces, healing places: Therapeutic landscapes of spiritual significance', Journal of Medical Humanities 36, 19-33. https://doi.org/10.1007/ s10912-014-9318-0

Peterson, E.H., 2005, Christ plays in ten thousand places: A conversation in spiritual theology, Eerdmans, Grand Rapids, MI.

Sachs, A., 2015, 'Lecture by Judge Albie Sachs about sites of memory, sites of conscience', Bloemfontein Courant, viewed 18 February 2019, from https://www. bloemfonteincourant.co.za/lecture-by-judge-albie-sachs-about-sites-of-memorysites-of-conscience/.

Saunders, D., 2010, Arrival city: How the largest migration in history is reshaping our world, Kindle edn., Random House, London.

Sparks, P., Soerens, T. \& Friesen, D.J., 2014, The new parish: How neighborhood churches are transforming mission, discipleship and community, Kindle edn., InterVarsity Press, Downers Grove, IL. 
Sweet, L., 2009, So beautiful: Divine design for life and the church, David Cook, Colorado Springs, $\mathrm{CO}$.

Talbot, A.-M., 2002, 'Pilgrimage to healing shrines: The evidence of miracle accounts', Dumbarton Oaks Papers 56, 153-173. https://doi.org/10.2307/1291860

Thiessen, J. \& McAlpine, B., 2013, 'Sacred space: Function and mission from sociological and theological perspective', International Journal for the Study of the Christian Church 13(2), 133-146. https://doi.org/10.1080/1474225X.2013.781911

Van Schalkwyk, P., 2006, 'Country of my skull/Skull of my country: Krog and Zagajewski, South Africa and Poland', Literator 27(3), 109-134.
Volf, M., 2019, For the life of the world, Kindle edn., Baker, Grand Rapids, MI.

Wepener, C., 2018, 'Om grond te romantiseer', Beeld, 07 April, viewed 15 February 2019 from https://www.netwerk24.com/Stemme/Aktueel/om-grond-te-romantiseer20180407.

Wikipedia, 2019, Heterotopia (space), viewed 19 February 2019, from https://en. wikipedia.org/wiki/Heterotopia_(space).

Wright, C.J.H., 2010, The mission of God's people: A biblical theology of the church's mission, Kindle edn., Zondervan, Grand Rapids, MI. 